\title{
Status and conservation of the ruddy-headed goose Chloephaga rubidiceps Sclater (Aves, Anatidae) in its wintering grounds (Province of Buenos Aires, Argentina)
}

\author{
Estado y conservación del cauquén colorado Chloephaga rubidiceps Sclater (Aves, \\ Anatidae) en su zona de invernada (Provincia de Buenos Aires, Argentina)
}

\section{DANIEL E. BLANCO ${ }^{1}$, SERGIO M. ZALBA ${ }^{2}$, CAROLINA J. BELENGUER ${ }^{2}$, GERMÁN PUGNALI ${ }^{3} \&$ HERNÁN RODRÍGUEZ GOÑI ${ }^{3}$}

\author{
${ }^{1}$ Wetlands International, 25 de Mayo $75810^{\circ} \mathrm{G}$ (1002) Buenos Aires, Argentina; \\ e-mail:dblanco@wamani.apc.org \\ ${ }^{2}$ Grupo de Estudios en Conservación y Manejo, Universidad Nacional del Sur, San Juan 670, (8000) \\ Bahía Blanca, Argentina \\ ${ }^{3}$ Asociación Ornitológica del Plata, 25 de Mayo $7492^{\circ} 6$ (1002) Buenos Aires, Argentina
}

\begin{abstract}
The mainland population of the ruddy-headed goose (Chloephaga rubidiceps) breeds in southern Patagonia and winters in the south of Buenos Aires province (Argentina), with a recent estimated size at around 900 individuals. This population is considered "in danger of extinction", while the Malvinas (Falkland) Islands population is in well conservation status, with an estimated size of 40,000 birds. The aim of this work is to contribute with updated information about the ruddy-headed goose's population wintering in southern Buenos Aires province. The specific objectives were to better delimit its wintering area, to look for sites with large numbers, to study its habitat used, and to identify main threats to the species. Two intensive surveys were conducted during the austral winter of 1999 . The results: (1) confirm the low abundance of the ruddy-headed goose supporting its critical conservation status, (2) corroborate its very restricted distribution, with more than $80 \%$ of sightings concentrated in an area of 13,000 ha in southern Buenos Aires province, and (3) suggest that changes in the species' habitat use during the wintering season appear to be a response to changes in habitat availability, resulting from the growth of crops and pastures. The overlap between the species wintering distribution and the main wheat cropping areas of Argentina results in serious threats to this goose. Management actions are discussed to contribute to the conservation of this endangered species.
\end{abstract}

Key words: ruddy-headed goose, conservation, management, distribution, habitat.

\section{RESUMEN}

La población continental del Cauquén colorado (Chloephaga rubidiceps) cría en el sur de la Patagonia e inverna en el sur de la provincia de Buenos Aires (Argentina), con un tamaño poblacional estimado recientemente en alrededor de 900 individuos. Esta población está considerada "en peligro de extinción”, mientras la población de las Islas Malvinas se mantiene en buen estado de conservación, con un tamaño estimado en 40.000 individuos. La meta de este trabajo es contribuir con información actualizada sobre la población de cauquén colorado que inverna en el sur de la provincia de Buenos Aires. Los objetivos específicos fueron delimitar con mayor precisión el área de invernada, buscar sitios con mayor abundancia, estudiar el uso de hábitat e identificar las principales amenazas para la especie. Durante el invierno austral de 1999 se realizaron dos censos intensivos. Los principales resultados son: (1) la confirmación de la baja abundancia del cauquén colorado, de acuerdo a su crítico estado de conservación, (2) su distribución muy restringida, con más del $80 \%$ de los registros concentrados en un área de 13.000 ha en el sur de la provincia de Buenos Aires, y (3) sugieren que los cambios en el uso de hábitat de la especie a lo largo de la temporada invernal, parecen responder a cambios en la disponibilidad de hábitat que resulta de la evolución de los cultivos y pasturas. La superposición entre el área de distribución invernal de la especie y la principal zona triguera de Argentina determina serias amenazas para este cauquén. Se discuten acciones de manejo con el fin de contribuir a la conservación de esta especie amenazada.

Palabras clave: cauquén colorado, conservación, manejo, distribución, habitat. 


\section{INTRODUCTION}

The ruddy-headed goose Chloephaga rubidiceps (Sclater, 1860) exists in two well-defined populations: a sedentary one restricted to the Malvinas (Falkland) Islands and a migratory one that nests in southern Patagonia (Chile and Argentina), and winters in southern Buenos Aires province (Argentina), where the distribution of the species overlaps with the upland goose (Chloephaga picta) and the ashy-headed goose (Chloephaga poliocephala) (Rumboll 1979, Canevari 1996, Madsen et al. in press).

Ruddy-headed geese were common in the continent until the end of the 1950's, numbering several thousand individuals and forming more than $50 \%$ of the total sheldgeese in northern Tierra del Fuego (Rumboll 1975). Since then the mainland population of the species has declined and today it seems to be close to extinction (Humphrey et al. 1970, Rumboll 1975, 1979, Canevari 1996), with a recently estimated size at around 900 individuals (Madsen et al. in press). An increase in nest depredation, resulting from the introduction of the Patagonian fox (Pseudalopex griseus) in the island of Tierra del Fuego in 1951, appears to be the main cause for the drop in the species numbers (Madsen et al. in press). By other hand the Malvinas (Falkland) Islands population is in well conservation status, with an estimated size of 14,000 to 27,000 pairs (Woods \& Woods 1997).

The status of this goose in its wintering grounds in southern Buenos Aires province is less known, and no historic population estimates exist. The scarce information available states that the species winters in a very reduced area located between the city of Tres Arroyos and the Atlantic coast (Rumboll 1979, Gibbons et al. 1998). Here sheldgeese have been traditionally persecuted by local farmers because they feed on crops and pastures and were declared an "agriculture pest" by the government in 1931 (Pergolani de Costa 1955). More recently, N.A. Tracanna \& L. Ferreira (unpublished results) and Martin et al. (1986) questioned the real magnitude of wheat losses caused by grazing geese and point out that situations in which sheldgeese come into conflict with agriculture are relatively few.

Nowadays the ruddy-headed goose has been excluded from the list of pest species due to the remarkable drop in its numbers (Rumboll 1975) and it is considered to be in danger of extinction in both, Argentina (García-Fernández et al. 1997) and Chile (Glade 1993). In the Buenos Aires province the species has been declared a "Natural Monument" (Provincial Law 12.250), a measure that involves the highest level of legal protection. But the problem is that farmers do not distinguish ruddy-headed geese from the other species (Martin et al. 1986, Canevari 1996), and sheldgeese are still considered harmful and in some areas aircraft are used to scare them away from wheat fields (R. Scoffield personal communication).

In addition to persecution by farmers in southern Buenos Aires province, wintering ruddyheaded geese are under additional threats such as hunting for sport (De la Balze \& Blanco 2002) and agrochemical poisoning. However, an assessment about the magnitude of these threats is still lacking.

The objectives of this study were: (1) to accurately delimit the ruddy-headed goose wintering area, (2) to identify sites with large numbers, (3) to gather baseline information about the species abundance within the region, (4) to characterize the habitat used by the species. This information, together with an analysis of current threats in southern Buenos Aires province, allowed us to suggest management actions that in combination with the protection of the species during breeding and migration periods are intended to contribute to its long-term conservation.

\section{MATERIAL AND METHODS}

\section{Study area}

The study was carried out at the ruddy-headed goose historical wintering area located in southern Buenos Aires province, Argentina (Fig. 1). This has been described as a polygon with the upper vertex in the city of Tres Arroyos, the lateral vertexes in Energía and Oriente villages (to the east and to the west, respectively) and with its base on the Atlantic coast (Rumboll 1979, Gibbons et al. 1998).

The region has a flat to moderately undulating relief and is crossed by many streams that flow into the Atlantic Ocean. Some places have a remarkable abundance of ponds and small lagoons. Climate is warm-temperate, with a mean annual temperature of around $13.4{ }^{\circ} \mathrm{C}$ and an annual rainfall of ca. $740 \mathrm{~mm}$.

The original native vegetation was of grassland steppe dominated by Stipa and Piptochaetium ("flechillar"), with abundant Poa, Melica, Briza, and Bromus species, among others (Cabrera 1994). However the landscape has been highly transformed by human activities and now there are hardly any remnants of the original vegetation left (Bucher \& Nores 1988). 


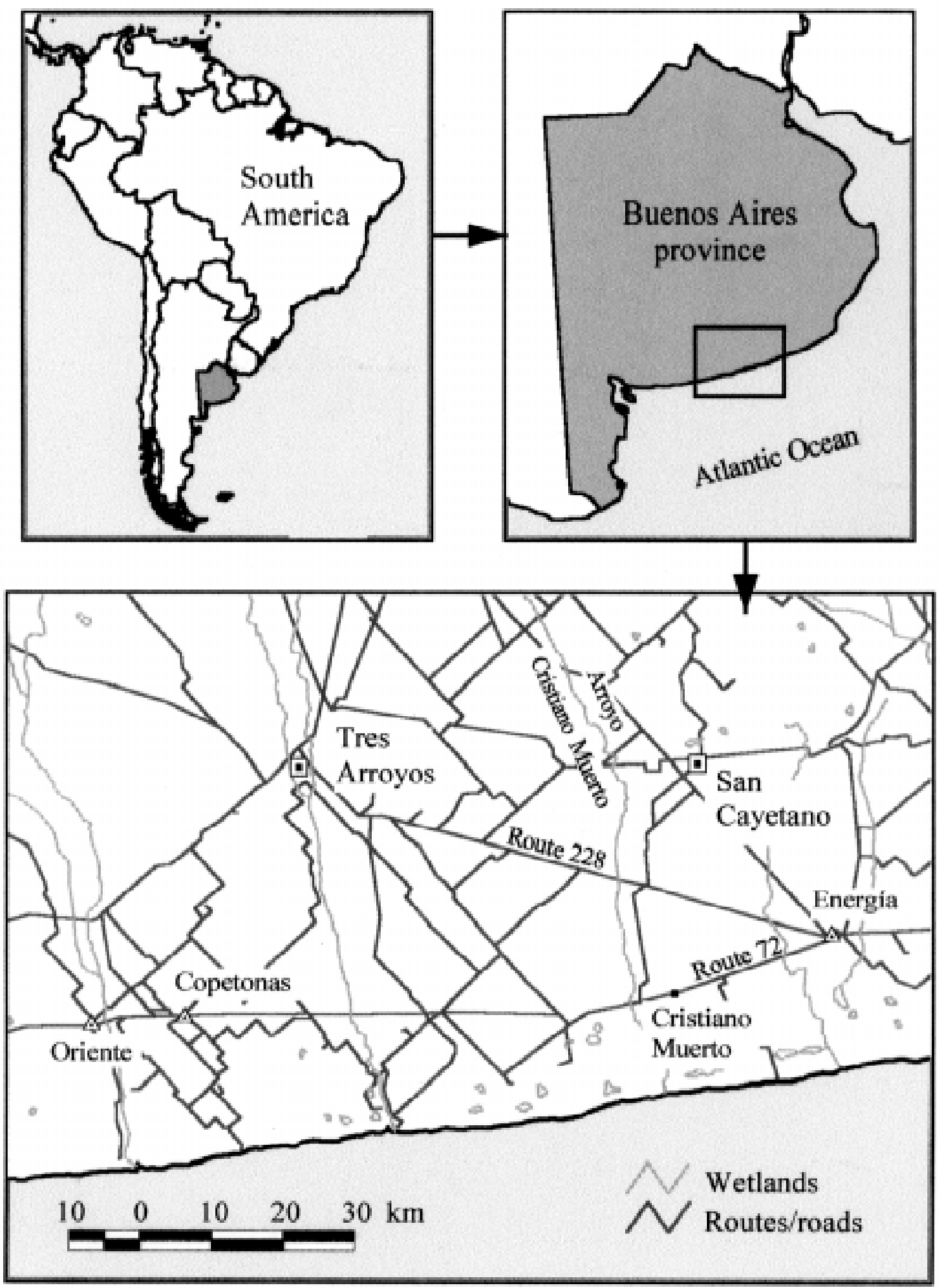

Fig. 1: Map of the study area in southern Buenos Aires province, Argentina. Mapa del área de estudio en el sur de la Provincia de Buenos Aires, Argentina. 
The region is predominantly under farming activities and can be depicted as a dynamic mosaic of crops, planted pastures and, to a much lesser extent, native grasslands. Wheat is the main crop, but there are also corn, sorghum, sunflower, and forages such as oats and white clover (N.A. Tracanna, S.I. Martin \& L Ferreira unpublished results).

\section{Methods}

This study was carried out during the austral winter of 1999 at the wintering grounds of the ruddy-headed goose. Two intensive surveys were conducted totaling eight days of field-work; the first survey in early July (five days) and the second one in late July-early August (three days).

We used the transect census method proposed by Davis \& Winstead (1980). Road transects totaling $2,278 \mathrm{~km}$ and covering a total area of 618,000 ha were surveyed: $1,389 \mathrm{~km}$ in early July and $889 \mathrm{~km}$ in late July-early August. The same sectors were covered in both surveys. Main and secondary roads were traveled by a vehicle at low speed, with two observers positioned one at each side of the car. Observations were made using $8 \mathrm{x}$ $40 \mathrm{~mm}$ binoculars and a $20-60 \times 77 \mathrm{~mm}$ zoomscope. Systematic stops were made when a geese group was detected, as well as when high borders of the road prevented proper scanning of the fields from the vehicle.

We recorded all geese groups observed in a strip of $300 \mathrm{~m}$ on both sides of the road, giving special attention to the presence of ruddy-headed geese. The following information was collected for each group: geographical position (with a Garmin-12 GPS), perpendicular distance from the group to the road (to the nearest meter), number of geese of each species, bird activity, type of habitat in which they occurred, and information about the characteristics of the field (vegetation, presence of wetlands, presence of cattle, etc).
To register the habitat type we used the categories adapted from N.A. Tracanna, S.I. Martin \& L Ferreira (unpublished results): (a) ploughed fields, (b) standing stubble fields (wheat, corn, sunflower), (c) ploughed stubble fields, (d) wheat fields with plants shorter than $5 \mathrm{~cm}$ (up to 25 days of growth), (e) wheat fields with plants taller than $5 \mathrm{~cm}$ (more than 25 days of growth), (f) young pastures, and (g) natural fields/old pastures, usually including some indigenous vegetation.

Both surveys were compared in terms of sheldgeese group size, the proportion of ruddyheaded geese and its mean abundance, by using the Wilcoxon-Mann-Whitney (WMW) test.

The number of goose groups recorded that included ruddy-headed geese (and the mean group size for this species) in the strips of $0-150 \mathrm{~m}$ and 150-300 m on both sides of the road, were compared using a Chi-square test, to search for possible effects of distance to road on geese abundance. Correlation analyses were performed to evaluate possible effects of distance to road on goose counts and abundance per species. The same analysis was used to search for potential differences in geese distribution during the study period. In this case group size and species composition were correlated with latitude and longitude data for each survey.

The birds' nomenclature follows Mazar-Barnett \& Pearman (2001).

\section{RESULTS}

Two hundred and ten groups with a total of 22,648 sheldgeese were recorded during the study. Forty one of these groups ( 27 at the beginning of July and 14 in late July / early August) included ruddyheaded geese, with means of 26 and 19 individuals per group respectively, and with a maximum count of 127 individuals (Table 1).

TABLE 1

Characteristics of ruddy-headed goose groups observed in early July $(n=27)$ and late Julyearly August $(\mathrm{n}=14), 1999$

Características de los grupos de cauquenes colorados registrados a principios de Julio $(\mathrm{n}=27)$ y a fines de juliocomienzos de agosto $(\mathrm{n}=14), 1999$

\begin{tabular}{lcc}
\hline Attribute & Early July & Late July-early August \\
\hline Mean ( \pm SD) C. rubidiceps/group & $26.15 \pm 38.76$ & $18.79 \pm 32.60$ \\
Maximum count of C. rubidiceps/group & 127 & 111 \\
Association to C. poliocephala & $89 \%$ & $79 \%$ \\
Association to C. picta & $56 \%$ & $79 \%$ \\
\hline
\end{tabular}


All ruddy-headed geese were observed between $38^{\circ} 30^{\prime}$ and $38^{\circ} 54^{\prime}$ latitude South, with more than $80 \%$ of the groups concentrated between $38^{\circ} 30^{\prime}$ and $38^{\circ} 36^{\prime}$, in the triangle limited by the provincial routes 228 and 72, to the west of Energía village (Fig. 2). Highest abundances were recorded in the surroundings of the Cristiano Muerto stream, south of provincial route 228 , where all the groups with more than 100 individuals were recorded. Solitary ruddy-headed geese and small flocks were also observed to the north of Orense, around Copetonas and along the provincial route 72, between Energía and Cristiano Muerto (Fig. 2).

The maximum daily count was of 284 ruddyheaded geese on July 8, 1999, distributed in two large groups that were feeding in two different fields $6 \mathrm{~km}$ apart, in the surroundings of the Cristiano Muerto stream. The species was generally found in mixed flocks with the two other geese (Fig. 3). Only once were ruddy-headed geese recorded as a monospecific group.
No significant differences were found when comparing both surveys in terms of sheldgeese group sizes (U -centered reduced statistic used for WMW test $=1.39, \mathrm{P}=0.17)$, proportion of ruddy-headed geese $(\mathrm{U}=0.14, \mathrm{P}=0.89)$ and its mean abundance $(\mathrm{U}=1.24, \mathrm{P}=0.22)$.

No significant differences were found when comparing the number of groups recorded that included ruddy-headed geese $\left(c^{2}=0.97, P=0.99\right)$ and the mean group size for the species $\left(c^{2}=0.31\right.$, $\mathrm{P}=0.86$ ) between the strips of $0-150$ and $150-300$ $\mathrm{m}$ from the road. Nor were any significant relationships found using correlation analysis between distance to the road and total group size ( $\mathrm{r}$ $=0.15, \mathrm{P}=0.88)$ and abundance per species $(C$. rubidiceps $\mathrm{r}=0.08, \mathrm{P}=0.84 ;$ C. picta $\mathrm{r}=-0.05$, $\mathrm{P}=0.91 ; C$. poliocephala $\mathrm{r}=0.12, \mathrm{P}=0.77)$.

Group size and composition were not correlated with the distance to the coast $(\mathrm{P}>0.75)$ nor with the position in the east-west axis $(\mathrm{P}>0.4)$. No changes were detected when the two surveys were analyzed separately.

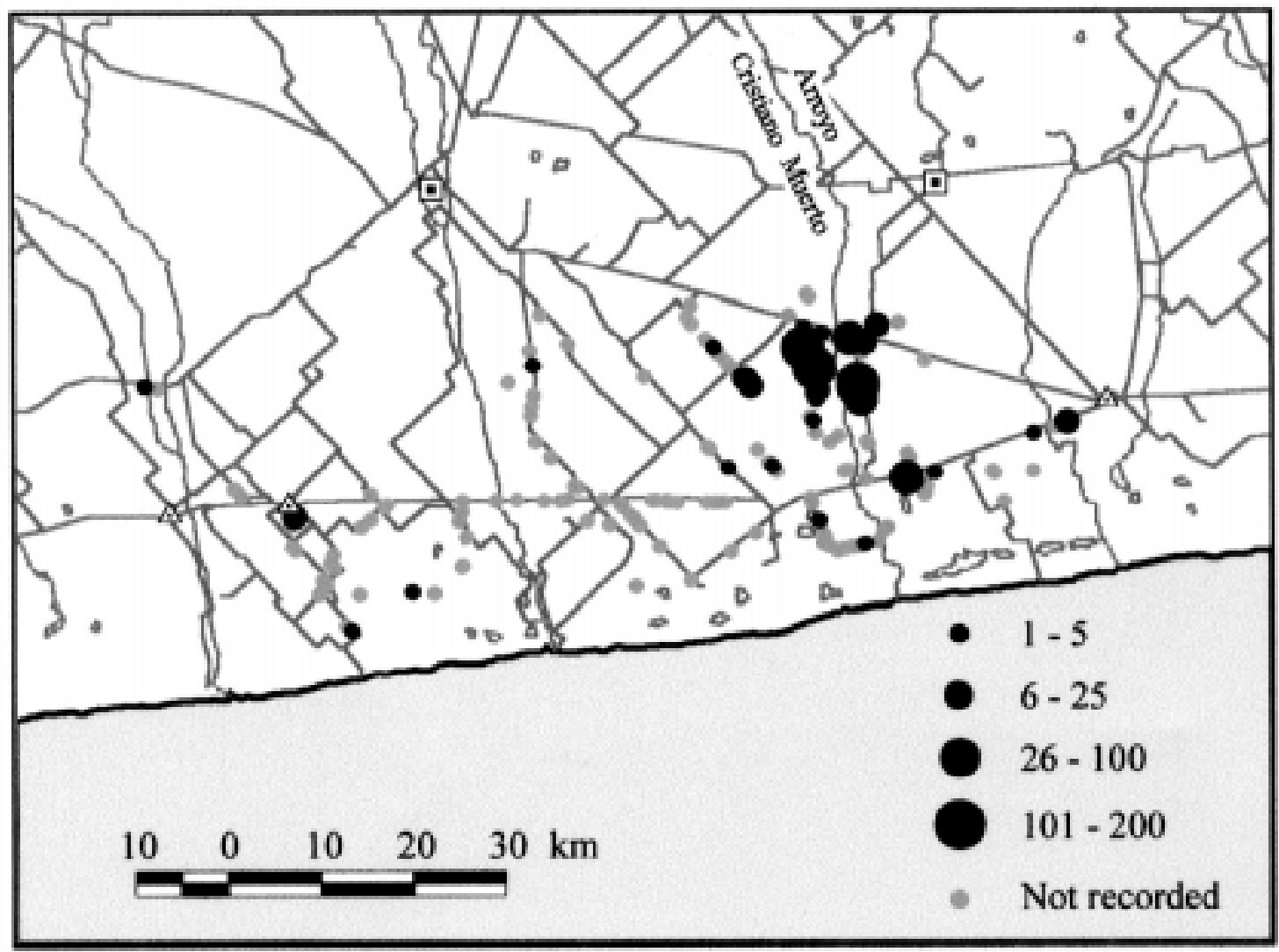

Fig. 2: Location of ruddy-headed geese groups (black circles) recorded during surveys in 1999. Gray circles indicate those groups composed by ashy-headed and/or upland geese.

Ubicación de los grupos de cauquenes colorados (círculos negros) registrados durante los censos de 1999. Los círculos grises indican aquellos grupos compuestos por cauquén real y/o común. 


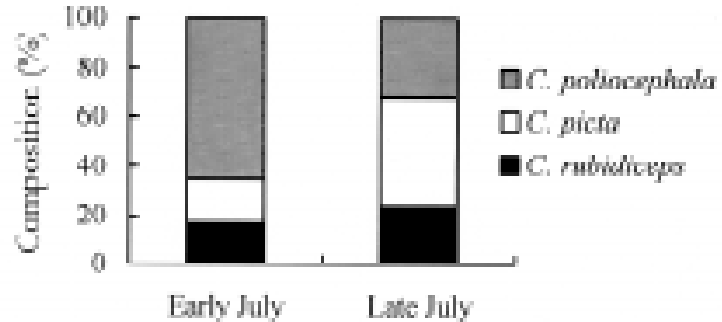

Fig. 3: Composition of ruddy-headed geese groups.

Composición de los grupos de cauquenes colorados.

\section{Habitat use}

By early July ruddy-headed geese were recorded feeding mainly on ploughed fields $(21.67 \%)$, young pastures $(22.52 \%)$-such as oat and cocksfoot Dactylis glomerata-, and natural fields (46.60 $\%$ ) (Fig. 4). Despite being a minor percentage of the study area (D. Blanco unpublished data), natural fields were used proportionately more by the species than other habitat types. These fields were mainly old pastures with more than two years of non-intervention, characterized by an heterogeneous vegetation, both in species composition and height (mean height $=14.80 \mathrm{~cm}, \mathrm{SE}$ $=1.57, \mathrm{n}=25$ ), and sometimes including a shrub strata of around $60 \mathrm{~cm}$ height. Some of these fields had an undulating relief and included marshes and temporary wetlands, where large flocks of roosting geese were recorded.

By late July-early August ruddy-headed geese were recorded feeding mainly on wheat fields $(45.24 \%)$ and oat pastures (48.24\%) (Fig. 4). Only once the species was recorded in a standing stubble of around $30 \mathrm{~cm}$ height. Groups of ruddyheaded geese were frequently seen in the vicinity of houses, silos and sheds, and around $4 \%$ of them were recorded in fields of grazing cattle.

When foraging in ploughed fields, ruddy-headed geese were observed feeding on wheat seeds lying on the ground. Other bird species recorded foraging in this habitat with the geese include white-faced ibis (Plegadis chihi), buff-necked ibis (Theristicus caudatus), Southern lapwing (Vanellus chilensis), tawny-throated dotterel (Oreopholus ruficollis), least seedsnipe (Thinocorus rumicivorus), kelp gull (Larus dominicanus), brown-hooded gull (Chroicocephalus maculipennis), eared dove (Zenaida auriculata), picazuro pigeon (Columba picazuro), and grassland yellow-finch (Sicalis luteola).
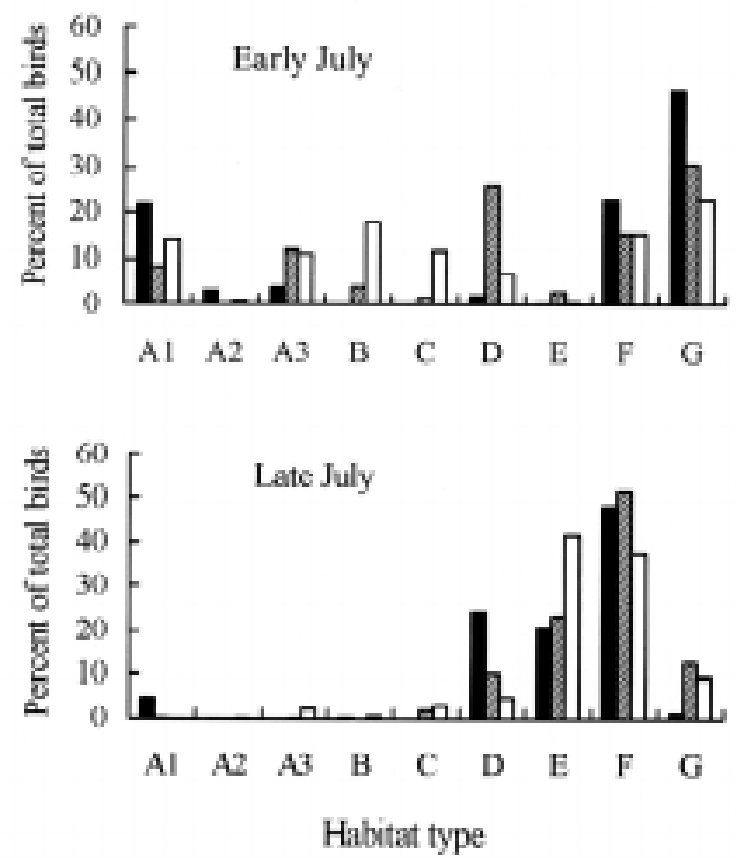

Fig. 4: Percent of total ruddy-headed geese (black), ashy-headed geese (diagonal lines) and upland geese (white) counted per habitat type: ploughed fields without vegetation cover (A1), or with stubble remains (A2), or with weeds (A3); standing stubble fields (B), ploughed stubble fields $(C)$, wheat fields with plants shorter than 5 $\mathrm{cm}$ (D), wheat fields with plants taller than $5 \mathrm{~cm}$ (E), young pastures (F) and natural fields/old pastures $(\mathrm{G})$.

Porcentaje de cauquenes colorados (negro), cauquenes reales (líneas diagonales) y cauquenes comunes (blanco) contados por tipo de hábitat: campos arados sin cobertura de vegetación (A1), o con restos de rastrojo (A2), o con malezas (A3); campos con rastrojo en pie (B), campos con rastrojo disqueado (C), cultivos de trigo con plantas de menos de $5 \mathrm{~cm}$ de altura (D), cultivos de trigo con plantas de más $5 \mathrm{~cm}$ de altura (E), pasturas jóvenes $(\mathrm{F})$ y campos naturales/pasturas abandonadas $(\mathrm{G})$.

\section{DISCUSSION}

Our results confirm the low abundance of ruddyheaded geese, supporting the current status of the species that is considered "in danger of extinction" in Argentina and Chile (Glade 1993, GarcíaFernández et al. 1997). Our maximum count did not exceed 300 ruddy-headed geese, reinforcing the idea that the mainland population of this goose is in the order of magnitude proposed by Madsen et al. (in press), who estimated it at around 900 individuals.

In spite of the similar habitat requirements of the three geese species during winter, our results 
corroborate the more restricted distribution of the ruddy-headed goose, with more than $80 \%$ of sightings concentrated in an area of approximately 13,000 ha in the surroundings of Cristiano Muerto stream, also suggested by other authors (Rumboll 1979, Martin et al. 1986, Knell \& Zelaya 1993, Gibbons et al. 1998). Repeated sightings in this area is in accordance with the fidelity to wintering areas phenomenon traditionally depicted for waterfowl species (Hochbaum [1944] 1982).

The absence of correlation between geese abundance and distances to roads, together with repeated observations of ruddy-headed geese feeding in the vicinity of houses and sheds, suggests that the species behavior is not conspicuously altered by human presence and activities, supporting the use of "road-surveys" to estimate population parameters. Surveys in early July coincided with the wheat planting season, which extends approximately from mid June to the end of July depending on the weather (J. RodríguezGoñi personal communication). In early July wheat fields were scarce and ruddy-headed geese were recorded feeding mainly on natural fields, pastures and ploughed fields. Here the species was observed feeding on wheat seeds or weeds that had emerged after rain. The potential value of geese as "weed-eaters" -including the annual rye grass (Lolium multiflorum), which appears to be highly palatable for the species-, was mentioned by N.A. Tracanna, S.I. Martin \& L Ferreira (unpublished results).

At the end of July there was a great overlap in the habitat use by the three geese species, with an increase in the use of wheat fields, pastures, and oat pastures. Changes in the ruddy-headed goose habitat use along the wintering season appear to be a response to changes in habitat availability, resulting from the growth of crops (mainly wheat) and pastures. This was also observed by N.A. Tracanna, S.I. Martin \& L Ferreira (unpublished results) and by Summers (1985) in the Malvinas (Falkland) Islands, where goose densities changed as newly sown crops and pastures germinated and developed.

Differing from the two other goose species, and mainly from the upland goose that showed a more general pattern of habitat use, ruddy-headed geese were not recorded in stubble fields during this study. However, other authors have observed the species on wheat, sunflower, and sorghum stubbles (Martin et al. 1986, Knell \& Zelaya 1993, Gibbons et al. 1998, N.A. Tracanna, S.I. Martin \& L Ferreira unpublished results), suggesting that habitat use should be considered as a dynamic phenomenon subjected to temporal (seasonal and inter-annual) changes.
Preliminary observations suggested a significant association of ruddy-headed geese to those fields with marshes or small lagoons, also mentioned by N.A. Tracanna \& L. Ferreira (unpublished results). The greater flocking of the ruddyheaded geese to the surroundings of Cristiano Muerto stream, south of route 228 , suggests a "hot spot" area, with a key value for the species conservation. An interesting issue is that the owner of the farm that was most used by the species does not perceive geese as a threat to wheat crops and does not scare the birds from his fields. So another aspect to consider is the relationship between the present ruddy-headed goose distribution and regional differences in past and present management practices directed at combating geese as a pest.

\section{The ruddy-headed goose conservation and management}

This work confirms previous remarks regarding the very small size of the ruddy-headed goose mainland population (Rumboll 1979, Vuilleumier 1994, Madsen et al. in press), the high concentration of the species and the overlapping of its wintering distribution with agriculture lands with the concomitant conflicts. The high concentration of ruddy-headed geese during winter results in an increased susceptibility to environmental stochastic forces that can condition its survival (Soulé 1987), but also a great opportunity to implement local and effective conservation measures (Blanco et al. 2001).

The creation of a reserve to protect the whole ruddy-headed goose wintering area does not seem a viable alternative, due to the fact that the land is expensive and privately owned. However, one option would be to create feeding stations on private property that could act as "mini-refuges" as has been done in North America and Europe with other waterfowl species (Patterson \& Fuchs 1991, Cox \& Afton 1998). These refuges should be located near to marshes and ponds, in those areas known to be used by the species. Geese could be attracted to these sites by using decoys and activities that might disturb the birds could be prohibited (Sugden [1976] 1982). Land owners should receive an economic compensation for setting aside part of their land for this purpose. Besides, the use of crop species that did not need to be harvested until after the geese had abandon the area could be recommended, and in this way the government would pay only for the effective losses due to geese grazing. These refuges would serve to keep geese out of other crop fields within 
the area, reducing the level of conflict between farmers and geese. Nevertheless, this measure by itself would probably not be enough to solve the problem, especially if the aim is to increase the ruddy-headed goose mainland population size.

Although some of the ruddy-headed geese would probably be hosted in the feeding refuges, other birds would rely on agricultural lands. The system of refuges should be complemented by other measures that would reward farmers for being tolerant to geese presence in their fields, as has been implemented in The Netherlands (van Paassen 1992).

In southern Buenos Aires province ruddyheaded geese appear to compete with farmers for crops and pastures, as it happens with geese and ducks in Europe and North America (van Roomen \& Madsen 1992, Ankney 1996). Real economic losses caused by geese may be minimal at the regional level, but the farmers' perception at a local scale is much greater and this is a critical aspect to consider for waterfowl conservation (Patterson 1992). On this regards, it is necessary to investigate the real magnitude of yield losses, as well as the potential of some mitigation measures, such as the use of scaring devices or economic compensations to farmers (Fox et al. 1991, Patterson 1991). Besides, positive interactions between geese and cattle should be assessed, as it was reported that geese faeces are used to feed the cattle in the Malvinas (Falkland) Islands (Summers \& Grieve 1982). Finally, it is essential to implement an informative/educational campaign about the critical status of the species and its conservation needs, mainly directed to teach people about how to differentiate the ruddy-headed goose from the other geese species.

\section{ACKNOWLEDGEMENTS}

This project received the financial support of the Convention on Migratory Species of Wild Animals (CMS-UNEP), and the institutional help of Wetlands International and the "Consejo Nacional de Investigaciones Científicas y Técnicas (CONICET)" of Argentina. We want to thank very especially Pablo Canevari (from Wetlands International), for his valuable guidance and advice. We miss him so much. We also want to thank the Rodríguez Goñi family, especially Javier, for his advice in agricultural matters, as well as the "Dirección Nacional de Fauna y Flora Silvestre", especially Sergio Goldfeder, for his assistance in the acquisition of a satellite image of the study area. Priscilla Minotti, Laura Benzaquén and Victoria de la Balze helped with
GIS matters. Thanks to Rosemary Scoffield for the revision of the English and helpful comments to the manuscript.

\section{LITERATURE CITED}

ANKNEY CD (1996) An embarrassment of riches: too many geese. Journal of Wildlife Management 60: 217-223.

BLANCO DE, R MATUS, O BLANK, L BENEGAS, S GOLDFEDER, F MOSCHIONE \& S ZALBA (2001) Manual para la conservación del cauquén (Canquén) colorado en Argentina y Chile. Wetlands International, Buenos Aires, Argentina. 31 pp.

BUCHER EH \& M NORES (1988) Present status of birds in steppes and savannas of Northern and Central Argentina. In: Goriup PD (ed) Ecology and conservation of grassland birds. ICBP Technical Publication 7: 71-79. International Council for Bird Preservation, Cambridge, United Kingdom.

CABRERA AL (1994) Regiones fitogeográficas argentinas. Enciclopedia Argentina de Agricultura y Jardinería, Tomo II, ACME, Buenos Aires, Argentina. 85 pp.

CANEVARI P (1996) The austral geese (Chloephaga spp.) of southern Argentina and Chile: a review of its current status. Gibier Faune Sauvage - Game \& Wildlife 13: 355-366.

COX RR \& AD AFTON (1998) Use of mini-refuges by female northern pintails wintering in southwestern Louisiana. Wildlife Society Bulletin 26: 130-137.

DAVIS DE \& RL WINSTEAD (1980) Estimating the numbers of wildlife populations. In: Schemnitz SD (ed) Wildlife management techniques manual (Fourth edition): 221-245. The Wildlife Society Inc., Bethesda, New York. USA.

DE LA BALZE V \& DE BLANCO (2002) El cauquén colorado (Chloephaga rubidiceps): una especie amenazada por la caza de avutardas. In: Blanco DE, J Beltrán \& V de la Balze (eds) Primer taller sobre la caza de aves acuáticas: hacia una estrategia para el uso sustentable de los recursos de los humedales: 119-122. Wetlands International, Buenos Aires, Argentina.

FOX AD, J MADSEN \& J VAN RHIJN (eds) (1991) Western Paleartic geese. Proceedings of the International Waterfowl and Wetlands Research Bureau Symposium. Ardea 79: 1-371.

GARCÍA-FERNÁNDEZ JJ, RA OJEDA, RM FRAGA, GB DÍAZ \& RJ BAIGÚN (eds) (1997) Libro rojo de mamíferos y aves amenazados de la Argentina. Fundación para la Conservación de las Especies y el Medio Ambiente, Sociedad Argentina para el Estudio de los Mamíferos, Asociación Ornitólogica del Plata \& Administración de Parques Nacionales, Buenos Aires, Argentina. $221 \mathrm{pp}$.

GIBBONS JE, R MATUS, YA VILINA, DE BLANCO, S ZALBA \& C BELENGUER (1998) Desarrollo de un plan de conservación para el cauquén cabeza Colorada (Chloephaga rubidiceps), en la región austral de Argentina y Chile. Corporación Nacional Forestal (Chile) $\&$ Wetlands International, Buenos Aires, Argentina. $40 \mathrm{pp}$. 
GLADE A (ed) (1993) Libro rojo de los vertebrados terrestres de Chile. Corporación Nacional Forestal, Santiago, Chile. 68 pp.

HOCHBAUM HA ([1944] 1982) A discussion for management. In: Ratti JT, LD Flake \& WA Wentz (eds) Waterfowl ecology and management - Selected Readings: 2-19. The Wildlife Society Inc., Bethesda, New York.

HUMPHREY PS, D BRIDGE, PW REYNOLDS \& RT PETERSON (1970) Birds of Isla Grande (Tierra del Fuego). Smithsonian Institution, Washington, District of Columbia. $411 \mathrm{pp}$.

KNELL A \& D ZELAYA (1993) Cauquén colorado: un viaje alentador. Nuestras Aves 28: 10-11.

MADSEN J, R MATUS, O BLANK, L BENEGAS, G MATEAZZI \& DE BLANCO (in press) Population status of the ruddy-headed goose (Chloephaga rubidiceps) in Tierra del Fuego and mainland Patagonia (Chile and Argentina). Neotropical Ornithology.

MARTIN SI, N TRACANNA \& R SUMMERS (1986) Distribution and habitat use of sheldgeese populations wintering in Buenos Aires Province, Argentina. Wildfowl 37: 55-62.

MAZAR-BARNETT J \& M PEARMAN (2001) Annotated checklist of the birds of Argentina. Lynx Ediciones, Barcelona, Spain. 164 pp.

PATTERSON IJ (1992) The need for crop damage mitigation in North American waterfowl conservation. In: van Roomen M \& J Madsen (eds) Waterfowl and agriculture: review and future perspective of the crop damage conflict in Europe. International Waterfowl and Wetlands Research Bureau, Special Publication 21: 53-58. IWRB, Slimbridge, United Kingdom.

PATTERSON IJ \& RME FUCHS (1992) Possibilities for waterfowl reserves from changing land-use practices. In: van Roomen M \& J Madsen (eds) Waterfowl and agriculture: review and future perspective of the crop damage conflict in Europe. International Waterfowl and Wetlands Research Bureau Special Publication 21: 71-77. IWRB, Slimbridge, United Kingdom.

PERGOLANI DE COSTA MJI (1955) Las avutardas: especies que dañan a los cereales y las pasturas. IDIA 88: $1-9$.
RUMBOLL MAE (1975) Notas sobre Anseriformes: el cauquén de cabeza colorado (Chloephaga rubidiceps): una nota de alarma. Hornero 11: 315-316.

RUMBOLL MAE (1979) El estado actual de Chloephaga rubidiceps. Acta Zoologica Lilloana 34: 153-154.

SOULÉ ME (ed) (1987) Viable populations for conservation. Cambridge University Press, Cambridge, United Kingdom. 189 pp.

SUGDEN LG ([1976] 1982) Waterfowl damage to Canadian grain: current problems and research needs. In: Ratti JT, LD Flake \& WA Wentz (eds) Waterfowl ecology and management - selected readings: 10561073. The Wildlife Society Inc., Bethesda, New York.

SUMMERS RW (1985) The size and composition of sheldgeese populations and their food consumption on different vegetation types in the Falkland Islands. Journal of Applied Ecology 22: 1-17.

SUMMERS RW \& A GRIEVE (1982) Diet, feeding behaviour and food intake of the upland goose (Chloephaga picta) and ruddy-headed goose ( $C$. rubidiceps) in the Falkland Islands. Journal of Applied Ecology 19: 783-804.

VAN PAASSEN A (1992) Integrating management measures: a case study to achieve coexistence between cost-effective agriculture and waterfowl. In: van Roomen M \& J Madsen (eds) Waterfowl and agriculture: review and future perspective of the crop damage conflict in Europe. International Waterfowl and Wetlands Research, BureauSpecial Publication 21: 61-70. IWRB, Slimbridge, United Kingdom.

VAN ROOMEN M \& J MADSEN (eds) (1992) Waterfowl and agriculture: review and future perspective of the crop damage conflict in Europe. IWRB Special Publication 21. International Waterfowl and Wetlands Research Bureau, Slimbridge, United Kingdom. 184 pp.

VUILLEUMIER F (1994) Status of the ruddy-headed goose Chloephaga rubidiceps (Aves, Anatidae): a species in serious danger of extinction in Fuego-Patagonia. Revista Chilena de Historia Natural 67: 341-349.

WOODS R \& A WOODS (1997) Atlas of breeding birds of the Falkland Islands. Anthony Nelson Ltd., Oswestry, United Kingdom. 192 pp. 